\title{
LA MIRADA DE ULISES. \\ UN VIAJE AL INFIERNO DE LOS BALCANES1
}

Pablo Huerga Melcón

IES Rosario de Acuña, Gijón

http://dx.doi.org/10.5209/NOMA.53768

\author{
Dedicado a Céfiro, \\ Asociación de profesores de Latín y Griego de Asturias
}

Resumen.- El presente artículo ofrece una interpretación filosófica de la película de Theo Angelopoulos (Grecia, 1995), La mirada de Ulises, en donde se sostiene que el argumento de la película está construido a partir del episodio odiseico de la visita a los infiernos, en el contexto de la guerra civil yugoeslava como símbolo de la derrota definitiva de los pueblos balcánicos para construir una gran nación política.

Palabras-clave: Angelopoulos, Grecia, Yugoeslavia, Balcanes, Guerra civil, Odisea, Ulises, cine, fotografía.

\begin{abstract}
Si es verdad que de esta naturaleza en constante transformación el artista jamás podrá utilizar más que un momento único, y si, además, el pintor no puede aprehender este momento más que desde un único punto de vista; si las obras dl artista están hechas no para ser vistas simplemente, son para ser contempladas -para ser contempladas despaciosa y repetidamente-, ¿̇qué duda cabe de que el artista nunca se habrá esforzado lo suficiente para lograr que este momento y este punto de vista únicos sean los más fecundos de cuantos puedan escogerse? Pero sólo es fecundo aquello que permite el juego libre de la fantasía. Cuanto más penetramos en una obra de arte, más pensamientos tiene que suscitar ella en nosotros. Cuantos más pensamientos suscite, tanto más firme debe ser nuestra convicción de que estamos penetrando en ella. (Lessing, Laocoonte, Tecnos, Madrid 1992; pág. 22.)
\end{abstract}

\footnotetext{
${ }^{1}$ El presente artículo es fruto de un trabajo realizado para la Asociación Céfiro de profesores de Latín y Griego de Asturias, en el marco del exitoso ciclo de cine griego que llevan organizando en el Antiguo Instituto Jovellanos de Gijón. Les agradezco la propuesta y la confianza.
} 
1. En la "Telemaquia" de la Odisea se relata el siguiente augurio: Telémaco ha ido a visitar a Menelao y mientras se estaban despidiendo,

"pasó por encima de ellos, hacia la derecha, un águila que llevaba en las uñas un ánsar doméstico, blanco, enorme, arrebatado de algún corral; seguíanla, gritando, hombres y mujeres, y al llegar junto al carro, torció el vuelo ala derecha, en frente mismo de los corceles".

Helena dijo entonces:

"Oídme, pues os voy a predecir lo que sucederá, según los dioses me lo inspiran en el ánimo y yo me figuro que ha de llevarse a cumplimiento. Así como esta águila, viniendo del monte donde nació y tiene su cría, ha arrebatado el ánsar criado dentro de una casa, así Odiseo, después de padecer mucho y de ir errante largo tiempo, volverá a la suya y conseguirá vengarse, si ya no está en ella, maquinando males contra los pretendientes todos."

Así nosotros nos encontramos ante la obra de arte, ante un cuadro, una fotografía, o una película. Es inevitable que acabemos viendo en ella aquello que, de alguna manera, esperamos que ocurra. Viendo La mirada de Ulises, una de las últimas películas de Theo Angelopoulos (Grecia 1995), enseguida queremos descubrir el argumento de la Odisea, el guión prefijado, el prejuicio con el que pretendemos verla. Sobre todo porque también Angelopoulos construye una película compleja, en la que muchos signos nos indican escenas diferentes y momentos distintos, en el contexto de la narración de Odiseo, pero en un marco ontológico radicalmente diferente. La película no recoge todo el contenido de la Odisea, esta solo aparece como elemento del título y, ciertamente, obedece al proyecto del director de hacer una adaptación de la Odisea. Sin embargo, no es un relato que pretenda una reconstrucción cinematográfica de la narración homérica. ¿̇Qué se esconde detrás de esta metáfora fílmica, de esta película profundamente conmovedora? Esto es lo que vamos a tratar de desentrañar en el presente artículo.

La mirada de Ulises comienza proponiendo un viaje en busca de los primeros rollos del cine grabados en los Balcanes por los hermanos 
Manakis, que fueron en la zona pioneros de la fotografía y del cine. Las imágenes grabadas se corresponden con los planos realizados por estos autores en una época en la que el cine todavía no era verdaderamente cine. Y esta es una de las ideas clave de la película. En efecto, el cine es el arte de recrear escenas y situaciones, no el de grabar acontecimientos directamente "del natural", podríamos decir. Cuando los hermanos Lumière inventaron el cine, lo concibieron así, como una máquina científica que podía contribuir al registro de situaciones y acontecimientos. Ellos entendían el cine como grabación documental, esto es, exactamente como hemos concebido nosotros lo que podríamos llamar la fotografía verdadera, aunque se trataría de una máquina capaz de grabar fotográficamente el movimiento. Pero es evidente que el cine ha evolucionado en una dirección diferente.

2. La fotografía, cuando es verdadera, cuando no está manipulada por ningún montaje, adquiere el don de la clarividencia temporal, nos permite recuperar y sostener en el presente continuo una imagen captada en un tiempo pasado, actuando como una especie de espejo retrovisor en el que queda fijada temporalmente la instantánea captada tiempo atrás, en un momento ya desaparecido. Por ello, tomando como referencia la teoría de la televisión que propone Gustavo Bueno en su libro, Televisión. Apariencia y verdad, (Gedisa, Barcelona 2000), decimos que una verdadera fotografía cuenta con la clarividencia temporal, es decir, nos permite ver en el presente una imagen proyectada "desde el pasado", por así decir. Ese pasado adquiere un efecto particularmente trágico cuando lo que queda grabado en la fotografía es la imagen de alguien que ya ha muerto, por ejemplo. Y de la misma manera que la fotografía tiene esa virtud de la clarividencia temporal, así también la tiene el documental cinematográfico, tal y como los hermanos Lumière 0 , en este caso, los hermanos Manakis, utilizaron el cinematógrafo, esto es, para grabar directamente de manera mecánica acontecimientos pasados en secuencias que reproducen el movimiento, sin montaje ni trucaje. En la fotografía verdadera, así como en la grabación cinematográfica documental, decimos que lo ocurrido es causa de la imagen, no se trata de que la imagen tenga un parecido con la realidad representada, es que hay una identidad causal entre la imagen vista y el objeto fotografiado.

Creo que estos argumentos permiten comprender mejor el sentido particular de la búsqueda del protagonista de la película, un director de 
cine afincado en EEUU (¿̇quizás la isla Ogigia de Calipso?), de origen griego, que regresa a su país, a Grecia, para buscar esas imágenes, esas cintas desconocidas. Se habla constantemente de esos rollos como si en ellos se encontrara recogida la expresión de una mirada inocente, una mirada primigenia. Pero żen qué sentido es primigenia esa mirada? Diríamos que tanto por lo que graba, la primera escena de los Balcanes, perdida en el tiempo, como por los personajes que miran a la cámara mientras son grabados, porque su mirada y su presencia es ingenua, no son aun espectadores. No hemos llegado a lo que se dice, por ejemplo, en La ventana indiscreta: "nos hemos vuelto todos una banda de mirones". No. Han sido precisamente el cine y la televisión quienes nos han convertido en unos mirones impenitentes, en espectadores de nosotros mismos y, por tanto, también en actores. Pero aquellos personajes grabados en 1905 no aparecen con la mirada del actor; miran sin comprender, o simplemente no miran, no se percatan de que están siendo grabados.

El cine originario, como la fotografía, es ante todo un "reflejo" de una realidad perdida. Lo que vemos en la imagen cinematográfica que Angelopoulos nos muestra en su película es real; es consecuencia de esas mujeres hilando en 1905 a la puerta de su casa. Por tanto, se diría que el cine documental, como la fotografía, cuando es verdadera, es clarividente, y nos permite ver, al igual que la televisión, a través de cuerpos opacos, a través del tiempo, que es lo más opaco concebible. Decimos muchas veces para hablar del pasado que "miramos atrás", pero atrás solo vemos el presente, el pasado es totalmente opaco a nosotros. Sólo la fotografía, o la grabación audiovisual, nos mantiene presente el pasado. Esa clarividencia hace de las primeras grabaciones cinematográficas, como de las primeras fotografías, la presencialidad más antigua concebible para el presente, lo más lejos que puede llegar nuestra mirada. Y así se concibe en la película la intención de poder contemplar las primeras imágenes de esa tierra balcánica, tal vez con la esperanza de que allí encontremos alguna respuesta, porque la indagación originaria adquiere sentido precisamente desde el presente al que han llegado esos mismos pueblos retratados en 1905. Tiene sentido también otorgar a esa imagen tanta importancia por lo que ella encierra de arcaico, puesto que los Balcanes es una tierra en cierto modo parada en el tiempo, hasta que irrumpe en ella el siglo XX, entre otras cosas, con esas mismas imágenes grabadas por los hermanos Manakis. 
3. La mirada de Ulises está entre esas películas que, por diversas razones, introducen en su montaje trozos de documentales en medio de una trama basada en una construcción artística, en una recreación. También lo hace, por ejemplo, aquella película de Stanley Kramer, Vencedores y vencidos (EEUU, 1961), en la que, en medio de los juicios de Nührenberg, se usan unos planos grabados en la liberación de los campos de Dachau o Bergen Belsen, para confirmar, corroborar, dar fe, de lo que los nazis hacían con los judíos. Una vez vistas las imágenes, y comentadas magníficamente por el fiscal, el juicio ha sido visto para sentencia. Los nazis son culpables. Diríase que el director de la película quiere ser también testigo de cargo.

En La mirada de Ulises el director inserta esos planos para remitirnos a la tierra perdida y confirmar esta evidencia. La inserción de estos documentales es también una prueba de que estamos en un doble plano, el plano de la representación que narra una historia, y el plano de la presentación documental de una verdad ocurrida en la que existe una relación causal entre el acontecimiento y la imagen grabada.

Aquí hay que distinguir entre el cine en sentido ordinario frente al cine documental. El cine en sentido ordinario es pariente del teatro. Lo decisivo, en el caso de las imágenes documentales y en la fotografía verdadera, es que existe una identidad o verdad de la imagen grabada por la cámara, y la imagen vista y proyectada en la sala de cine. Una verdad por adecuación física o causal como la de la televisión, mientras que la verdad cinematográfica no documental solo puede reclamar una identidad por semejanza, como dice G. Bueno, en La fe del ateo (ed. Temas de hoy, Madrid 2007; pág. 324). Y, a la inversa, las grabaciones documentales no pueden proyectar acontecimientos no ocurridos y falsos, mientras que el cine representacional sí puede hacerlo $y$, de hecho, lo hace, porque su verdad no está en la adecuación, ni siquiera por identidad de semejanza, porque el cine no quiere adaptarse o buscar la semejanza con la realidad, el cine mismo forma parte de la realidad construida por el hombre, y la mímesis es necesariamente construcción; en la misma intención de recrear la realidad la construye conforme a lo verosímil, como dice Aristóteles. No obstante, es obvio que una fotografía o una grabación audiovisual supone siempre el uso de un punto de vista, pero esto no es relevante para lo que estamos diciendo, al fin y al cabo, es imposible concebir la percepción de la "realidad" sin hacer uso de un determinado y concreto punto de vista. 
De hecho, es importante señalar lo que ocurre con los Lumière cuando en 1897 van con sus aparatos cinematográficos a grabar in situ una representación de la pasión de Jesucristo que se hacía en Horitz, un pueblo de Babiera. Los Lumière, "sin querer" -diríamos- comienzan a hacer cine de verdad, el cine como representación. Graban un viacrucis pero finalmente lo que ocurre es que graban la representación teatral de la muerte de Cristo precisamente como si hubieran prefigurado, sin hacerlo, decorado, escenarios, actores, plató, story board, guión, y todo lo demás. Graban el teatro y de esa manera hacen una verdadera película cinematográfica cuando pretendían hacer un documental. El cine como arte nace ya con Méliès, con el uso de escenario, montaje, trucaje, actores, y guión, y comienza a saltar del escenario teatral para introducir un mayor efecto realista con autores como Eisenstein, que a través del teatro acaba haciendo cine porque necesita introducir cosas imposibles en el escenario, trenes, edificios.

4. Puede decirse, en gran medida, que el cine nace cuando comienza a ser imitación, es decir, cuando reproduce a su modo y con sus propios medios acontecimientos no ya reales, sino posibles, verosímiles, diciéndolo en el sentido de la mímesis que propone Aristóteles en La Poética. Allí define todo arte por la mímesis, distinguiéndose entre sí las diferentes artes por los medios de que se valen para ello, en lo que el cine adquiere una dimensión artística neta precisamente cuando deja de ser documental. Aristóteles no conoció el cine, y sin embargo, en su definición de tragedia estableció los elementos básicos para su propia definición. La tragedia, es imitación, pero no de los hombres, dice Aristóteles, sino de las acciones, de la vida, de la felicidad y de la desdicha. Lo mismo podemos decir del cine. De hecho, los caracteres de los personajes se entienden a su vez como resultado de sus propias acciones (1450b-aVI). Aristóteles propone además que la tragedia es imitación de una acción acabada y completa que tiene una adecuada extensión (1450aVI). Por completa entiende que debe tener principio, medio y fin, siendo el principio aquello que de por sí no sigue necesariamente a otra cosa, "pero después de ello hay o se produce algo de un modo natural".

Es decir, que el inicio de la trama debe ser desligable causalmente del resto de lo que se recoge en la tragedia: disociable; de la misma manera que el final, que también debe ser disociable de lo que siga a la acción. Para comprender cabalmente el planteamiento aristotélico, creo que sería necesario introducir un elemento esencial en la propia 
conformación de la duración de la acción, asumiendo que ésta debe tener un inicio, un medio y un fin. Porque la disociación de la acción con respecto al continuo biográfico se establece mediante la introducción de la prolepsis, es decir, de la intención o el proyecto de una acción. La acción, para que sea cinematográfica -o trágica-, debe ser resultado de un plan, de un fin, aunque ella no represente la consecución de ese fin, sino, por ejemplo, su imposibilidad manifiesta, lo que dará a la historia un carácter trágico, por ejemplo. Por ello, dice Aristóteles, "aquellos que construyen bien los argumentos no deben comenzarlos al azar." De la misma manera, La mirada de Ulises nace con el inicio de un viaje que sigue a una intención, a una finalidad establecida en el continuo biográfico, tal vez por lo que le ocurrió en la isla de Delos, donde "se quedó sin mirada", según dice. (Por cierto que, en este sentido, también se trata del viaje a los infiernos de un director que busca volver a encontrar su propia mirada, el sentido de su trabajo; esta idea está presente también en la película de Fellinni, Fellini ocho y medio (Italia, 1963); en ella, el director protagonista busca recuperar su creatividad a través del reencuentro con sus mujeres. También, en La mirada de Ulises, A. se reencuentra con cuatro mujeres diferentes que son, al mismo tiempo, la misma actriz, y que recogen, por otra parte, las mujeres de Odiseo, desde Calipso, Circe, Nausica y Penélope. Es de señalar, asimismo, que en la adaptación cinematográfica de Mario Camerini (Ulises, Italia 1954), Calipso, Circe y Penélope son interpretadas por la misma actriz Silvana Mangano, prefigurando la propia decisión de Angelopoulos.)

Y con respecto a la unidad de la acción, también los apuntes de Aristóteles resultan ser esenciales. La unidad de la acción no procede del hecho de que se centre en torno a un solo personaje (1451aVIII) "puesto que a un solo personaje le ocurren muchas e infinitas cosas, algunas de las cuales no comportan unidad alguna". "En cambio, Homero, que destaca asimismo en otros aspectos, parece que también intuyó esto, ya sea por su arte o por su genio, ya que, al componer la Odisea, no relató todo lo que le sucedió a Ulises como, por ejemplo, que había sido herido en el Parnaso, y que se fingió loco cuando tuvo lugar la concentración de la hueste, pues ninguno de esos dos hechos era necesario o verosímil que ocurriera habiendo ocurrido uno de ellos: al contrario, compuso la Odisea en torno a una sola acción, e igualmente hizo con la llíada". 
En el cine, cada película recorta el conjunto de interacciones que el desarrollo de un plan personal tiene en el conflicto con otros planes y programas, tanto generales como personales. Y así como la Odisea recorta una acción, y no toda la vida de Odiseo, sino el plan de llegar a Ítaca y recuperar su poder, de la misma manera, La mirada de Ulises recorta, dentro de toda la trama odiseica, sólo una acción, aquella que se refiere al viaje a los infiernos de Ulises, porque ese viaje le va a permitir al director construir una metáfora de la historia entera de los Balcanes.

La película, como la tragedia, es, en definitiva, una symploké en el sentido platónico, el despliegue de un entramado, de un tejido compuesto por diversos hilos que se anudan en esa unidad de acción, al igual que las propias vidas y, a otra escala, al igual que la propia historia de los pueblos. De esta manera, podemos integrar dentro de la trama de la película los planos originales de los hermanos Manakis de esas hilanderas. Pues ellas representan la imagen misma de la esencia del cine como urdidor de tramas, siendo esos documentales uno de los hilos de la trama de La mirada de Ulises. Y la propia película parte de la trama de la historia de los Balcanes.

5. La importancia, por tanto, de la búsqueda de Ulises, de esa mirada, está ligada al hecho de la verdad recogida en esos documentales, una verdad que nos permitiría adentrarnos, por así decir, en aquellos acontecimientos y tiempos en los que todavía no había entrado el siglo $X X$, unos tiempos prístinos, sin historia, plagados de posibilidades, que finalmente sufrieron una historia, y les fue trazado un camino que, claramente, no se corresponde con los deseos del director, el cual, al regresar al pasado, manifiesta la nostalgia del tiempo en el que todo pudo haber sido hecho de una manera manifiestamente diferente. Pero, entre aquel principio y su actual momento, ha transcurrido la historia, una historia en la que todo ha cambiado, plagada de muertos.

En La cámara lúcida (Paidós, Barcelona 2011; pág. 33-34) Roland Barthes dice: "Imaginariamente, la Fotografía (aquella que está en mi intención) representa ese momento tan sutil en que, a decir verdad, no soy ni sujeto ni objeto, sino más bien un sujeto que se siente devenir objeto: vivo entonces una micro-experiencia de la muerte (del paréntesis): me convierto verdaderamente en espectro [...] pero, cuando me descubro en el producto de esta operación, lo que veo es que me he convertido en Todo-Imagen, es decir en la Muerte en persona; los otros -el Otro- me despojan de mí mismo, hacen de mí, 
ferozmente, un objeto, me tienen a su merced, a su disposición, clasificado en un fichero, preparado para todos los sutiles trucajes [...] En el fondo, a lo que tiendo en la foto que toman de mí (la "intención" con que la miro) es a la Muerte: la Muerte es el eidos de esa foto." Cada uno de los instantes de esas fotografías son presente mientras yo los veo, cuando muero son historia.

Según esto, el viaje que emprende Ulises no solamente es un viaje geográfico a Sarajevo, lugar donde se encontrarían, al parecer, las grabaciones, sino también un viaje a través del tiempo. La geografía y la historia se funden en el viaje por el que transitan los muertos con los que Ulises se va encontrando. Como si La mirada de Ulises no fuera otra cosa sino un viaje a los infiernos, a través de los lugares y los tiempos que jalonan la vida de Ulises, y la propia vida de esa geografía balcánica por la que transcurre la vida de los hombres. Un viaje a los infiernos, porque es un viaje al pasado, pero también es un viaje de vuelta a casa, porque regresa de algún modo al lugar originario, a su patria.

Por ello, la película, a pesar de estar plagada de referencias de la Odisea, no es una reconstrucción de la misma, ni sigue la pauta general de la historia. De hecho, la Odisea es el viaje de vuelta a casa de Odiseo, pero lo que aquí se busca son unas grabaciones, parece más bien el viaje de Jasón y los Argonautas en busca del Vellocino de oro. Hay además muchas ausencias en la película, y algunas presencias que obligan a forzar demasiado la interpretación para situar figuras y personajes de la Odisea que sólo encajan si hacemos una comparación estructural entre película y poema épico. Es curioso, por ejemplo, que algunos autores sitúan el famoso viaje a los infiernos de Ulises en la Odisea justo al llegar a Florina, donde masas de gente se enfrentan con paraguas. Algunos piensan que aquí es donde se produce el viaje a los infiernos de Ulises, mientras que otros lo ven en la entrada en Albania, con esas gentes perdidas en la bruma. Otros, sin embargo, encuentran la ese descenso en la entrada de Bucarest, donde el protagonista, sin dejar de ser él, se encuentra con su madre en los años cuarenta en Constanza, y después con toda su familia. Pero esta cuestión no queda zanjada aquí. Es verdad que Ulises se encuentra con gigantes como el cíclope Polifemo y los Lestrigones, comedores de hombres, y así también se encuentra en medio del Danubio con la estatua gigante de Lenin recién demolida. Pero żes posible no ver aquí también otro episodio del viaje a los infiernos, cuando Ulises se encuentra precisamente con Agamenón y con Aquiles? Ambos muertos en Troya, han contribuido a 
transformar el mundo, pero el mundo heroico que ellos representaban también ha muerto, igual que el comunismo. ¿No es posible ver a ese Lenin convertido en una sombra, en un espectro, en la misma imagen de Aquiles en el encuentro con Odiseo? Ciertamente, aquí otra vez caemos en la cuestión de qué queremos ver. Pero el comunismo para los Balcanes fue lo más parecido a la única esperanza política del siglo XX y su época significó la modernización absoluta e irreversible de todos los países balcánicos. Algo que por ejemplo, para nosotros, emponzoñados en montañas de manipulación informativa durante décadas, somos incapaces de comprender. $\dot{Y}$ cómo interpretar de nuevo la visita a Belgrado sino en términos de la propia aventura infernal? ¿ $\dot{\imath}^{N o}$ es acaso su amigo el que le indica el lugar en el que puede encontrar esas grabaciones, el mismo Tiresias del viaje a los infiernos? Y ¿̇cómo interpretar, a su vez, el viaje remontando el río, sino es como un camino de entrada hacia el Tártaro?

Algunos han querido interpretar el capítulo final de Sarajevo como la tierra de los feacios, ¿́pero es posible encontrar parecidos con los feacios que llevan a casa a Ulises, le honran y dignifican, le visten y le alimentan, con el núcleo de la guerra de los Balcanes, donde se va a encontrar, ni más ni menos, que con el almacén de sombras completo y catalogado en la supuesta filmoteca. Un lugar lleno de sombras. Por tres veces, dice Ulises, intentó abrazar a su madre, pero su espectro se desvanecía entre sus brazos. Y entonces lloró Odiseo. Es verdad que el barco de los feacios desapareció convertido en roca al regreso de su viaje a Ítaca portando a Odiseo, y aquí mueren todos una vez que Ulises ha encontrado lo que busca, pero la presencia de la muerte es aquí radical. Acaso Ulises ha llegado a casa y la encuentra vacía y destruida $y$, sin arco para vengar tanta barbarie, llora de impotencia. Pero ciertamente, la mirada de Ulises parece más bien un viaje a los infiernos de Dante, y menos el regreso a casa de un héroe perdido.

6. Y de hecho, esta es la tesis que nosotros defendemos, en relación con La mirada de Ulises. La película adapta y recoge bajo las coordenadas históricas correspondientes a la destrucción de los Balcanes, después de la esperanza fundada que supuso para esta región el desarrollo de los estados comunistas del siglo XX, un solo acontecimiento de la Odisea, aquel que aparece recogido en el Canto XI. Aquel en el que Odiseo, siguiendo el consejo de Circe, se acerca a las puertas del Hades para consultar con Tiresias el camino que debe seguir para llegar a Ítaca. Odiseo debe invocar a los muertos por medio de una serie de rituales en 
virtud de los cuales comienzan a acercarse las ánimas del inframundo. En un primer momento, estas ánimas vienen en tropel y Odiseo debe sacar la espada para evitar que se acerquen puesto que primero de todo debe dar de beber la sangre a Tiresias. Allí "se congregaron, saliendo del Érebo, las almas de los fallecidos: mujeres jóvenes, mancebos, ancianos". "Agitábanse todas con grandísimo murmullo alrededor del hoyo, unas por un lado y otras por otro, y el pálido terror se enseñoreó de mí". La correspondencia de esta escena de la Odisea con el capítulo que trascurre en Florina es casi literal, de modo que efectivamente podemos considerar la entrada de A. en Florina como el inicio de ese viaje a los infiernos.

Una vez que hubo consultado con Tiresias el camino de regreso, este también le dijo cómo poder hablar con las demás ánimas, es decir, dándoles a beber la negra sangre -su particular "revelado". Así habló con su madre, a quien consulta acerca de sus familiares. Ulises pretende abrazar a su madre. Por tres veces lo intenta en vano: "iMadre mía! ¿Por qué huyes cuando a ti me acerco, ansioso de asirte, a fin de que en la misma morada de Hades nos echemos en brazos, el uno del otro y nos saciemos de triste llanto? ¿̇Por ventura envióme esta vana imagen la ilustre Perséfone, para que se acrecienten mis lamentos y suspiros?"

En efecto, Ulises confunde la sombra de su madre, la imagen o el espectro, con ella misma, y no la puede abrazar: "No te engaña Perséfone, hija de Zeus, sino que ésta es la condición de los mortales cuando fallecen: los nervios ya no mantienen unidos la carne y los huesos, pues los consume la viva fuerza de las ardientes llamas tan pronto como la vida desampara la blanca osamenta, y el alma se va volando como un sueño."

Así pues, la imagen que Odiseo alcanza a ver de los muertos llega a confundirlo de tal forma que los ve como reales, aunque son sólo espectros. Así A. el protagonista de la película, buscando las primeras imágenes grabadas por el cinematógrafo de los Manakis a través de los Balcanes, viaja a los infiernos, donde sólo pueden encontrarse sombras.

Seguidamente, recibe la visita de "cuantas mujeres fueron esposas o hijas de eximios varones." Con la espada desenvainada fue permitiendo que una por una bebiera la negra sangre, y con todas fue hablando. Este episodio estaba recogido también en la película, aunque finalmente quedó eliminado, y ocurría entre Belgrado y Sarajevo, en donde sólo queda montado un episodio entre el protagonista y una 
campesina búlgara. Pero al parecer, en el guión original se trataba de un grupo de mujeres: "Según el material rodado, tras la partida de Belgrado, una pequeña embarcación dejaba a $A$. en la ciudad destruida de Vukovar. Allí se refugiaba en un edificio en el que también lo hacía un grupo de mujeres. Posteriormente, unos soldados irrumpían violentamente en el lugar, persiguiendo y forzando a las mueres. Una de ellas, -la campesina búlgara- se refugiaba en el escondrijo donde se encontraba A. y posteriormente se producida el cambio de época, momento en el que se inicia el plano montado." (Pere Alberó, Theo Angelopoulos. La mirada de Ulises, Paidós, Barcelona 2000; p. 45)

Después de este episodio, Odiseo refiere el encuentro con Agamenón y con Aquiles, quizá el más famoso de ellos, pues en él Aquiles se lamenta de haber muerto tan joven, a pesar de la fama y el recuerdo eterno de que gozará entre los mortales. Agamenón le refirió también su propia muerte en manos de Clitemnestra y Egisto.

Nuevamente, Aquiles recuerda a Odiseo su condición: "żcómo te atreves a bajar a la mansión del Hades, donde residen los muertos, que están privados de sentidos y son imágenes de los hombres que ya fallecieron?" Odiseo le honra con estas palabras: "Pero tú, joh Aquiles!, eres el más dichoso de todos los hombres que nacieron y han de nacer, puesto que antes, cuando vivías, los argivos te honrábamos como a una deidad, y ahora, estando aquí, imperas poderosamente sobre los difuntos. Por lo cual, joh Aquiles!, no has de entristecerte porque estés muerto." Pero Aquiles le dice: "No intentes consolarme de la muerte, esclarecido Odiseo: preferiría ser labrador y servir a otro, a un hombre indigente que tuviera poco caudal para mantenerse, a reinar sobre todos los muertos."

Después de intentar hablar con Ayax y saludar a Heracles, Ulises quedó inmóvil, por si acaso venía algún héroe de los que murieron anteriormente. "Y hubiera visto a los hombres antiguos a quienes deseaba conocer (a Teseo y a Pirítoo, hijos gloriosos de las deidades), pero congregóse, antes que llegaran, un sinnúmero de difuntos con gritería inmensa, y el pálido terror se apoderó de mí, temiendo que la ilustre Perséfone no me enviase del Hades la cabeza de Gorgo, horrendo monstruo."

En La mirada de Ulises, A. remonta el río Danubio, como un nuevo Aqueronte, hacia las puertas del infierno, y después de visitar a su madre, de intentar abrazarla impotente, se encuentra con la estatua de 
Lenin que viaja desmontada sobre un barco hacia su nuevo destino irónico -propiedad de un magnate alemán coleccionista. Lenin ha sido muchas veces interpretado en esta película como el cíclope Polifemo, sin embargo no hay ninguna razón para entenderlo así, a parte del desmesurado tamaño de la escultura. Cierto que el capitán del barco dice que en su barco va Nadie, pero A. mira de frente la cabeza de Lenin que le devuelve la mirada hierático. Lenin es, sin duda, Aquiles, el más dichoso de todos los hombres, "puesto que antes, cuando vivías, los eslavos te honrábamos como a una deidad, y ahora, estando aquí, postrado camino del infierno, imperas poderosamente sobre los difuntos". En la orilla del río las gentes despiden la estatua como si de un dios se tratara, se asoman, se arrodillan y rezan. Lenin no es un monstruo Polifemo, salvo para los cursis occidentales capitalistas que hemos visto una pálida imagen de los Balcanes, siempre bajo la estúpida reinterpretación de los medios de comunicación, excesivamente prejuiciosos acerca del comunismo. Pero para los Balcanes, y para Grecia, el comunismo no sólo fue la gran oportunidad histórica, sino la época de paz y prosperidad más larga de esta zona, y también la desgracia de Grecia que, en la pugna por integrarse en dicho modelo, sufrió la guerra civil y la desestabilización constante durante todo el siglo $X X$.

Si queremos buscar a Tiresias, tenemos que ir a Belgrado, donde por fin su amigo del alma, sabio y también perdido en el tiempo y la memoria, le indica el lugar y el camino para alcanzar las sombras que busca: Sarajevo. Sarajevo será, para A. el mismo infierno, la muerte de sus compañeros, la de los feacios que le llevan a Ítaca, la de la familia del director de la filmoteca, la del alquimista que podrá hacer visibles aquellas sombras escondidas; que le abrirá, por fin, la última puerta del infierno donde quedan recogidas y convenientemente catalogadas todas las sombras grabadas en los Balcanes; la filmoteca que guarda la memoria de un mundo perdido definitivamente en la historia. A. llora ante la constatación de que todo lo que queda de ese territorio prometeico son las sombras escondidas que sólo se animan con la sangre, igual que las películas de los Manakis requieren también una mezcla exacta de productos químicos para volver a vivir como sombras, para hacerlas visibles y comprensibles.

Y ¿̇qué decir de las imágenes primeras, grabadas por los Manakis? Esas hilanderas de Abdella que aparecen en la película, cuando dejamos de verlas solamente como documentos de otra época, y las integramos 
en la narración de La mirada de Ulises, resulta que se convierten en las Moiras, o las Parcas, que van hilando la vida de los hombres de los Balcanes, prefigurando su destino en el siglo XX, la historia del tiempo en el que los Balcanes tuvieron, y perdieron, la oportunidad de ser una gran nación. Ellas hilaron el destino de los pueblos, y a su tiempo cortaron el hilo de ese destino desamparándolos de nuevo ante la historia.

7. Entonces, en la película La mirada de Ulises distinguimos tres dimensiones fundamentales: por una parte, el viaje y su estructura episódica, marcada seguramente por los nueve capítulos que propone el interesante trabajo que sobre esta película ha hecho Pere Alberó citado anteriormente; por otro lado tenemos el espacio geográfico por el que transita el viaje mismo, que es el territorio de los Balcanes, y que atraviesa Grecia, Albania, Macedonia, Bulgaria, Rumanía, Serbia, y Bosnia-Herzegovina; como tercer eje tenemos que situar ni más ni menos que la historia por la que transita el viaje, porque hemos visto que el viaje de A. no es solo un viaje geográfico, sino temporal, histórico. La geografía y la historia se articulan dialécticamente en el viaje y se manifiestan en él.

El viaje, por así decir, nos pone en evidencia el núcleo esencial del problema histórico de la región de los Balcanes, que no es otro que la división, la separación entre fronteras, la lucha fratricida, y el fracaso para superar las rencillas y conflictos interétnicos. Tan constitutivo resulta el problema que precisamente ha dado nombre a esa categoría social política e histórica: la balcanización. Pero ¿qué es la balcanización? Esta palabra se utiliza para expresar precisamente el proceso de descomposición de un territorio en diversas partes enfrentadas, un proceso que no tiene lugar de manera pacífica, sino violenta, con una violencia particularmente acerba. Por lo tanto, balcanización supone la ruptura de una unidad política en partes divergentes. Hoy se habla del peligro de balcanización de México, del peligro de balcanización de España, etc. Y ciertamente, se trata de un peligro real y muy importante. Pero ¿̇por qué? ¿̇Acaso el proceso de balcanización es ni más ni menos que un ideal basado en el principio de autodeterminación de los pueblos, en virtud del cual es no solo posible, sino necesario, la descomposición de los estados en entidades más pequeñas y manejables para alcanzar la verdadera libertad? ¿ ${ }^{N}$ o es el ideal de la llamada "Europa de los pueblos"? 
$Y$, aunque el paradigma de la ruptura y disgregación de un estado en sus partes divergentes procede de los Balcanes, sin embargo, como dice Francisco Veiga en su libro fundamental sobre esta región, La trampa balcánica. Una crisis europea de fin de siglo (ed. Grijalbo, Barcelona 1995), ni fue más cruento o terrible que en otros lugares de Europa, ni el fenómeno de los nacionalismos tuvo mayor virulencia que en cualquier otro lugar de Europa. Seguramente la balcanización habrá que referirla no tanto al hecho de la descomposición, cuanto al hecho de no haber sido capaces de construir una unidad posible superior.

Ahora bien, si balcanización supone una unidad previa que se resquebraja, habría que plantearse de qué tipo de unidad estamos hablando. Porque, por ejemplo, podría tratarse de una unidad política, lo que nos obligaría a remitirnos al marco del imperio otomano, que es en donde se sitúa la última unión política efectiva de los Balcanes. Una unidad que, sin embargo, cubriría otros muchos territorios no correspondientes a la península balcánica, sino también Turquía, Siria, Palestina, Egipto. De modo que esa unidad está por encima del modelo que buscamos. Tal vez se trata de la unidad de los Balcanes resultante de la lucha contra el imperio otomano que comienza por Grecia y que podría interpretarse como una de las líneas de fuerza de la lucha contra el imperio que acabaría resquebrajándolo. Pero entonces esta unidad ya no es política efectiva, sino meramente coyuntural, o estratégica. Los Balcanes, como tal, nunca han sido un estado político efectico. Por lo tanto, curiosamente la balcanización no habría tenido lugar en los Balcanes. Algo que por ejemplo, el historiador Francisco Veiga ha dejado bastante claro en el libro que antes hemos mencionado. No obstante, nos parece que Angelopoulos insiste en la nostalgia de la unidad balcánica, no precisamente con relación al imperio otomano, sino a una unidad que pudo haber sido y no fue.

8. La balcanización es una de las categorías fundamentales de la teoría política. En ella se dan cita la dialéctica de los estados, la idea de Estado, la idea de Nación, Etnia, o ideas como la de Libertad política, etc. Pero para entender el alcance de la nostalgia de Angelopoulos, es preciso partir de una teoría filosófica del Estado. Tomaremos como referencia la teoría materialista del Estado que ofrece Gustavo Bueno en su Ensayo sobre las categorías de las ciencias políticas. Según esta teoría, en el estado hay que distinguir la conformación de tres capas constitutivas, la capa basal que se refiere precisamente al territorio marcado por unas fronteras y organizado técnicamente a lo largo de la 
historia. Aunque esto pudiera remitirnos a la idea de la base 0 infraestructura de la teoría social de marxismo, se diferencia de ella porque hablamos de territorios organizados por el trabajo $y$ transformados técnicamente por los hombres, y es evidente que no todos los territorios pueden quedar circunscritos a un mismo nivel de desarrollo en cada época. Aunque pueda haber grandes rasgos semejantes, no es lo mismo el nivel de desarrollo que tenía por ejemplo España en la época de la conquista de América que un estado como Francia, o Gran Bretaña, aun pequeñas sombras de lo que habrían de ser después. La capa basal supone un territorio y unas fronteras definidas no solo por la línea de separación, sino por el desarrollo de caminos, canales, puertos, vías de comunicación, roturación de la tierra, cuidado de los bosques, ríos, estado de las aguas, explotación de recursos, etc. Por otra parte, estaría la capa conjuntiva, que remite al marco de relaciones sociales, económicas y políticas que regulan la vida de los individuos dentro del estado. Y finalmente, estaría la capa cortical que tiene que ver con las fronteras y con la defensa del territorio por parte de los ejércitos, así como las relaciones exteriores entre los estados. En este sentido, ¿̇qué es lo que otorga unidad al estado? Su capacidad para defenderse del ataque exterior, por supuesto, y su capacidad para sostener la unidad interna de entre las diversas tendencias divergentes que se generan necesariamente en toda sociedad política, porque entendemos una sociedad política como aquella que está compuesta de partes entre las cuales existe conflicto y en las que al menos una de las partes es capaz de imponer un orden e integrar en la unidad a las diversas partes divergentes.

Así, creo que la nostalgia de Angelopoulos tiene que ver con el hecho de haber constatado que, una vez roto el imperio otomano, se abrió la vía para la unidad de los pueblos balcánicos, precisamente porque se trataba de una situación en la que diversos pueblos étnicos, entremezclados territorialmente de manera muy intensa, pudieron tener la oportunidad de aspirar a una unidad política superior, es decir, estatal, en la medida en que cristalizaran proyectos políticos capaces de actuar fuera de la lógica reaccionaria de las tendencias étnicas y raciales. Es decir, la esperanza de construir, a partir de las diversas naciones étnicas, una nación política. La primera propuesta histórica que ofreció una oportunidad ideal de integrar bajo un molde estatal las diversas etnias divergentes de los Balcanes fue precisamente la guerra de independencia griega del siglo XIX que dio lugar al nacimiento de Grecia como estado moderno. Porque los griegos no habrían luchado 
en un principio por establecer el mini-estado que hoy constituyen, sino una unidad política basada en los ideales racionales que alimentaron la energía de los románticos que fueron a Grecia a luchar y morir. Ese primer ideal se llamó precisamente "la gran idea" (megali idea) y fracasó. "En esencia, dice Francisco Veiga, "se trataba de reconstruir el Imperio bizantino, en clara competencia con las aspiraciones rusas a una "Tercera Roma"." (pág. 75). El otro gran proyecto de unión territorial de los Balcanes vendría en diversas oleadas de los serbios. Como dice Francisco Veiga: "De todos los proyectos expansionistas barajados en los Balcanes, sólo los griegos y los serbios lograron darles cierta envergadura, marcando su propia historia y la balcánica durante el siglo XIX." (pág. 74). Finalmente, el comunismo como gran ideal racionalista y universalista habría permitido también dar carta de naturaleza a la posible integración en una especie de macro-estado balcánico. En este caso, el proyecto tuvo su epicentro no en Grecia, sino en Yugoeslavia. Pero este proyecto también fracasó.

El fracaso de estos proyectos es un ejemplo claro de lo que constituye la dialéctica de los estados. La razón por la que fracasaron tiene dos raíces diferentes: una correspondiente a la propia debilidad interior del estado naciente, o la leve disposición para actuar conforme a este plan de integración política (en este caso esta debilidad venía alimentada por los odios étnicos y raciales, amén de religiosos, que suelen, por otra parte, exagerarse más de lo debido, según el propio Francisco Veiga, y también por la ineficacia del propio imperio otomano para generarlos); otra razón tendría que ver con la fuerza de otros estados para promover la desunión y fomentar el fracaso. En el primer caso, el interés del Imperio Austro-Húngaro por evitar a toda costa que mejorara la situación en su frontera sur, junto con los propios intereses de Rusia y Turquía, así como de Inglaterra que, aliada de Turquía, luchó siempre para evitar la conformación de esta nueva unidad política, hizo imposible la megali idea de los griegos. En el segundo caso, el pacto entre EEUU y la URSS de separar sus zonas de influencia, y el hecho de que Grecia quedara del lado "oscuro", hizo imposible la unión, y llevó a Grecia a toda una serie de conflictos que jalonaron el siglo XX, debido a la insistencia con la que los griegos quisieron integrarse en el proyecto comunista general de los Balcanes.

Después de estos dos grandes fracasos históricos, solo la indómita Yugoeslavia sostenía alguna esperanza de uniones regionales, pero la guerra civil auspiciada y alimentada por las nuevas demandas de la 
unidad alemana acabaron echando por tierra la última esperanza, y sumieron a los eslavos del sur, y a los "griegos romanos", en esa sensación de derrota definitiva y desesperada que recoge La mirada de Ulises.

Balcanización significaría, por tanto, a la luz de la propia historia de los Balcanes, el conjunto de estrategias de las que se valen algunos imperios para desgajar territorios amenazantes utilizando las propias debilidades internas que esos territorios comportan, con el fin de poder someterlos e integrarlos en el radio de acción de esos imperios. Una forma particular de sembrar el caos y la destrucción si es necesario, que permite ejercer el dominio. Balcanizar remite a un tipo de imperio, a aquel que Gustavo Bueno ha llamado, en España frente a Europa (Alba editorial, Barcelona 1999) imperio depredador. Y, en efecto, los Balcanes fueron asediados por imperios depredadores como el británico, el austro-húngaro, o el nazi. Sólo durante la época del expansionismo soviético vivieron los Balcanes una época de paz y progreso, porque el imperio soviético, como el español, fue un imperio generador. De la misma manera, en los propios efectos que ha tenido para los Balcanes, se puede ver el carácter del nuevo imperio europeoalemán, que para afianzar su poder necesitó triturar Yugoeslavia. El nuevo imperio euro-alemán, en colaboración con el angloamericano, esto es, la OTAN, es también un imperio depredador sembrador del caos, como podemos observar en Irak, Libia, Egipto, Siria (antes en Hispanoamérica, por supuesto, y aun ahora sigue trabajando para desestabilizar Hispanoamérica de todas las maneras posibles) y ahora mismo en estos momentos, en Ucrania, lugar donde se han hecho evidentes y explícitos todos los entramados estratégicos organizados para abrirse camino hacia Rusia, destruyendo Ucrania. De estos asuntos, al parecer, ya habría advertido con claridad a los rusos el último presidente de Yugoeslavia.

En definitiva, la historia de los Balcanes es, en gran medida, la historia de la impotencia para construir un estado, una impotencia que queda reflejada de manera particularmente amarga en La mirada de Ulises. 


\section{Bibliografía}

Pere Alberó, Theo Angelopoulos. La mirada de Ulises, Paidós, Barcelona 2000.

Theo Angelopoulos, La mirada de Ulises, Grecia 1995.

Aristóteles, Poética, Trad. José Alsina Clota, ed. Bosch, Barcelona 1985.

Roland Barthes, La cámara lúcida, Paidós, Barcelona 2011.

Gustavo Bueno, Televisión. Apariencia y verdad, Gedisa, Barcelona 2000.

Gustavo Bueno, España frente a Europa, Alba editorial, Barcelona 1999.

Gustavo Bueno, en La fe del ateo, ed. Temas de hoy, Madrid 2007.

Gustavo Bueno, Primer ensayo sobre las categorías de las ciencias políticas, Biblioteca riojana, Logroño 1991.

Mario Camerini, Ulises, Italia 1954.

Fellinni, Fellini ocho y medio, Italia, 1963.

Homero, Odisea, Trad. Luís Segalá y Estalella, Sociedad General Española de Librería, Madrid 1982.

Pablo Huerga Melcón, La otra cara del Guernica, Zahorí ed., Gijón 2009. Stanley Kramer, Vencedores y vencidos, EEUU, 1961.

Francisco Veiga, La trampa balcánica. Una crisis europea de fin de siglo, ed. Grijalbo, Barcelona 1995. 